\title{
'On yestern day, in Feverere, the yere passeth fully': On the Dating and Prosopography of Mankind ${ }^{1}$
}

Both the beginning and the end of the twentieth century were marked by critical studies of the late medieval English morality play Mankind. The first of these was Walter K. Smart's 1916 article, 'Some Notes on Mankind'. 2 Smart considered the prosopography of ten men named in the play who would likely have been known to the audience, and suggested a rough date (Shrovetide, 1471) and location (Cambridge or Bishop's Lynn) for the play's original performance. The second study was John Marshall's 1997 “'O Ye Souerns That Sytt and Ye Brothern That Stonde Ryght Wppe": Addressing the Audience of Mankind'. ${ }^{3}$ Marshall also examined the historical context of the play, and through a study of the play itself and a study of East Anglian guild records, presented a compelling (if suppositional) argument that the play was performed on Saturday, 23 February 1471, at either the Cambridge or Bishop's Lynn guildhall of the St Edmund Guild, or at a Dominican church in one of the two towns. The play, according to Marshall, would have been sponsored by and performed for the St Edmund Guild, and authored by Cambridge graduate and Dominican Nicholas Meryll, who moved from Cambridge to Bishop's Lynn sometime between 1458 and 1475. This current study cannot hope to verify conclusively Smart's or Marshall's hypotheses. It will, however, follow them in method, and through further consultation of royal and local records, prosopographical studies, and other literary analyses of the play, fill in occasional gaps in the data, and suggest further possibilities regarding the original context of the play.

While all internal and external evidence for the play has directed most scholars to accept the Shrovetide 1471 date as the most compelling possibility, few studies have considered the national events of the period, and the potential repercussions they may have held for local politics and local drama. The Shrovetide festivities that would have included the play fell within the so-called Lancastrian Readeption, the seven months from October 1470 to 
April 1471 when Henry VI reclaimed the English throne during the struggles now called the War of the Roses. During these factional battles, the local gentry were employed by both Lancastrian and Yorkist peers and the crown to consolidate power in the counties. Their ability to retain the gentry's loyalty, however, was frequently in doubt during the fifteenth century. By noting the ties between local and national politics during fifteenth century, the political and judicial roles that those named in Mankind played, and themes within the play itself, this study will suggest that Mankind may carry a politically subversive message, affiliating itself with the king in exile and praising loyalty and steadfastness in a politically uncertain time. More specifically, it will be shown that of the ten men named, only the three (William Alington, William Hamond, and Alexander Wood) avoided by the worldlings Newguise, Nowadays, and Nought are known to have held offices under Edward IV and to have been tied to Yorkist peers.

To understand how national events affected local politics, it is important to understand the methods employed by the peerage and the crown to maintain authority in the counties, and how these methods changed over the fifteenth century. Any effort to find a direct and easy correspondence between the desires of the nobility or the crown and activities on the local level is bound to meet with failure, for, as Watts puts it, 'the informal dealings of king and nobility at the centre combined with a formal framework of the royal administration to produce a workable and representative from of justice in the localities' ${ }^{4}$ This formal framework of royal administration ran alongside a less formal system of livery and personal household retainers for the nobility, a system which had the ability to influence both national politics and local drama, as has been made clear in the example of the Suffolks and their clients in East Anglia in the 1440s, and another Macro play, Wisdom.

Bertram Wolffe has noted that Henry VI failed 'to stand up to the unscrupulous pressure under which he made his grants and appointments. ${ }^{5}$ Wolffe cites by way of example that 'William de la Pole, earl of Suffolk, the household steward, surpassed all his predecessors and competitors in the acquisition of major offices, with all of the powers and patronage they each entailed', ${ }^{6}$ and that Suffolk 'personified the abuse and prostitution of royal power in the localities to private ends which had become a hallmark of Henry's personal rule'. ${ }^{7}$ Many of Suffolk's official gains sprang from his close ties to Henry as councillor and mentor; as Griffiths discusses at length, 'the changes of personnel in the offices of state and the royal household before the royal crisis of 1449-50 reinforced Suffolk's unmistakable dominance and 
elevated a group of household servants dependent on him'. ${ }^{8}$ Among these household servants were certain East Anglian law-breakers, whom de la Pole sponsored for local offices in Suffolk and Norfolk, including Sir Thomas Tuddenham. Tuddenham acted as both MP and sheriff for Norfolk, shared stewardships of lands with Suffolk himself throughout East Anglia, and served on a number of judicial commissions, including commissions of the peace and commissions of oyer and terminer. ${ }^{9}$ Tuddenham was known for neglecting to pursue his criminal associates, 'forcing juries to perjure themselves, issuing forged returns and inquisitions, retaining against the law, making unjust presentments and imprisonments, exacting obligations of money by threats and menaces, falsely outlawing men, manipulating the customs due on wool exports and overawing lawcourts'. ${ }^{10}$

Suffolk's affinity transcended the boundaries between local and national politics, as well as political and personal networks of patronage. The breadth of his affinity is nowhere as clear as in his support of Tuddenham and his associates. Tuddenham had no direct ties to the peerage, but his association by marriage in the 1420 s to the Wodehouse family brought him into contact with local magnates who were in turn tied to the nobility of Norfolk and Suffolk, including Thomas Beaufort, duke of Exeter, and the successor to Exeter's local clientage, William de la Pole. As a result, Tuddenham was able to receive, through Suffolk's interest, positions of local and royal authority, positions that Tuddenham could employ to his and Suffolk's benefit. Further, Tuddenham's own clients were then likewise able to benefit by gaining employ in Tuddenham's ventures. Tuddenham's clients included John Heydon, a Norfolk lawyer who 'championed the duke's [Suffolk's] interests and advanced his own by threats and naked force ... John Wymondham, who resorted to threats and violence in 1448-49 as easily as Heydon; William Prentis, who usefully manipulated juries and was one of Tuddenham's rougher henchmen; and John Ulveston'. ${ }^{11}$

The strength of these local networks was largely dependent on the favour that their noble patron had at court. Tuddenham was dismissed from a number of his offices in the same year that saw William de la Pole's downfall. The changes begun in the royal household, however, could take their time in reaching the localities, or indeed might not be felt at all. After his 1450 dismissal, Tuddenham maintained his ties with the de la Poles, and was treasurer of the royal household from 1458 until 1460, when Edward IV's ascendency led to a commission of Tuddenham's arrest and eventual execution in 1462. ${ }^{12}$ Tuddenham's end reflects a larger attempt by the Yorkist throne to 
regain control of the realm, in which both household positions and political offices were filled with Yorkist loyalists. Griffiths points out that Henry VI, once captured by the Yorkists, found his household 'in the process of being cleansed of its Lancastrian courtiers and servants', and 'found himself surrounded by men whom he had not chosen, many of whom may not have been familiar to him, and who were intended to be his keepers rather than his companions' ${ }^{13} \mathrm{He}$ adds that 'Yorkist control was no less complete over the offices of state', and that 'the recasting of government, like that of the household, penetrated below the senior levels' ${ }^{14}$ citing the need for new sheriffs, the recovery of 'property and positions forfeited', and the due promotion of 'those who had aided their enterprise'. ${ }^{15}$ These recovered lands that would have been given to Yorkist peers necessitated stewards, not to mention local authorities willing to support the transition. This consolidation of power by Edward IV led to a general waning in the power of liveried household retainers, replacing this older system with one more transparent, with loyal local men receiving political and judicial appointments. Here, at this intersection of national and local politics, the old networks of patronage that defined the gentry in the localities could be implemented to engage with new loyalties. This willingness to accept and work with new lords in large part defines local power structures, as I will discuss further below in relation to Mankind.

The effect that national and local power structures - and Suffolk's abuse of them — had on local drama is apparent in the play Wisdom. Through his careful reading of Wisdom's precise and detailed stage directions, beginning with a direction that the evils of Mayntennance (696) should wear 'rede berdys, and lyouns rampaunt on here crestys' (directions after 692), John Marshall contends that the bearded head and the lions evoke 'a fairly unambiguous sign of the Suffolks for an audience with adverse knowledge or experience of their activities in East Anglia' ${ }^{16}$ For a play which discusses the ills of maintenance, perjury, and lechery, the Suffolks would fit as an immediate and near-contemporary example of the effects of those ills when unchecked. The inclusion of a concrete contemporary illustration of vice in Wisdom need not diminish the overall theme of the play, and may well serve to underscore the point. An abstract discussion of good and evil, already personified, can be made even more tangible to the audience if the connection to their time and place is as direct as is the case in Wisdom.

The benefits to scholarship of reading contemporary politics into morality plays extends beyond discovering themes opaque to modern readers; such hints may also determine the likelihood of various performance venues 
and authorship. Although the monastery of Bury St Edmunds has long been supposed to be a potential site of authorship for the Macro plays, Marshall argues that the anti-Lancastrian tone of the Wisdom makes such a conclusion unlikely:

If there are sufficient clues in the text of Wisdom to invite the audience to make a connection between the vices portrayed and the Suffolks, then there are clear implications for the nature of the original audience ... A satirical view of the Suffolks would also seem to disqualify the claim for a performance in the monastery of Bury St Edmunds. William de la Pole and Alice Chaucer were both admitted to the chapter fraternity of the abbey during the time of Abbot Curteys (1429-1446), who regarded Suffolk as his "grete lord" Unless there was a dramatic change in allegiance, the abbey was, perhaps, unlikely to have played host to a play that was, apparently, critical of the past and present associate members. ${ }^{17}$

The possibility that Wisdom was intended to be read this way is only supported only by an attempt to read another Macro text, Mankind, the same way. Although Mankind lacks the detailed stage directions of Wisdom, Mankind does contain the names of ten Norfolk and Cambridgeshire men. If we accept Marshall's dating of the play, then we can predict that the original audience of St Edmund Guild members, in either Cambridge or Bishop's Lynn, would have reacted (probably with amusement) to hearing the names of associates, friends, or enemies mentioned when Titivillius tells his three henchmen to go and rob or otherwise stir up trouble among them:

Tityuillus. I know full well what Mankynde dyde to yow;

Myschyff hat informyde of all pe matere thorow.

I xall venge yowr quarell, I make Gode avow.

Forth, and espye were ye may do harme!

Take William Fyde, yf ye wyll haue ony mo.

I sey, New Gyse, wethere art pou avysyde to go?

New Gyse. $\quad$ Fyrst I xall begyn at Master Huntyngton of Sauston.

Fro thens I xall go to Wylliam Thurlay of Hauston,

Ande so forth to Pycharde of Trumpyngton-

I wyll kepe me to pes thre.

Nowadays. I xall goo to Wyllyham Bakere of Waltom,

To Rycherde Bollman of Gayton.

I xall spare Master Woode of Fullburn- 


He ys a noli me tangere.
Nought. $\quad$ I xall goo to Wyllyam Patryke of Massyngham;
I xall spare Master Alyngton of Botysam,
Ande Hamonde of Soffeham,
For drede of in manus tuas qweke!
Felous, cum forth, and go we hens togethyr.

Of the ten men listed, one, 'William Fyde', is enlisted as a helper to the worldings, seven are sought out to be done harm, while three, Masters 'Woode', 'Alyngton', and 'Hamonde' are considered men to be avoided. The lucky three are unique within the list according to two important parameters. Firstly, they are the only three who held positions of authority in Cambridgeshire during or before the Shrovetide festivities of 1471. This fact leads to the second commonality between the three men: they are the only three that can, with the evidence we possess, be directly tied to Edward IV and his Yorkist peers before and during the Readeption through bonds of local and household offices and marriage. Despite the loss of Yorkist authority during Shrovetide 1471 in East Anglia, these men would likely be known and respected by either a Yorkist audience or an audience that was currently reexamining its political loyalties in the face of potentially permanent Lancastrian rule. Among such audiences, the overacted caution on the parts of the worldlings would humorously display the gifts that loyalty brings, while possibly criticizing those who are tempted by the possibility of rising in the gentry under the Lancastrians.

As can be seen from the quotation above, however, the listing of names is not entirely clear, and no specific date is given within the play. To ensure that the brief and sometimes unclear references to the Cambridgeshire men do indeed point to a Shrovetide 1471 performance date, a brief recapitulation of earlier datings of the play, beginning with Walter Smart in 1916, moving to Mark Eccles' critical edition of the play from 1969, and concluding with Marshall, will justify the likely accuracy of Marshall and Smart.

Smart considered the terminus a quo for the authorship to be 1465 , based on a coin mentioned by Nowadays: 'Gyf ws rede reyallys yf ye wyll se hys abhomynabull presens' (465). The gold royal was first coined in 1465, and the play could not, therefore, have been written before that point. ${ }^{18}$ Donald Baker clarified this argument in 1963, by adding that although royals were in fact in circulation from 1464, a later date, probably 1466, was preferable to allow the coin to gain popularity. ${ }^{19}$ Smart also first identified the most certain 
terminus ad quem as 1474 , based on the inscription at the end of the play: 'O liber, si quis cui constas forte queretur, Hyngham quem monacho dices, super omnia constas [O book, if perchance anyone asks to whom you belong, say that you belong to Hyngham the monk, above all]'. ${ }^{20}$ Believing that the monk was Richard Hengham, who became abbot of Bury St Edmunds in 1474, Smart concluded that he 'would, therefore, not designate himself as plain "monk" after that date'; Smart's faith in this identification has since been quite convincingly challenged, with a Thomas Hyngham of the same monastery being a more likely owner. ${ }^{21}$

Smart, however, had further evidence for a date in the 1470 s, citing the mock record of the court read by Mischief, which sets the year as follows:

Curia tenta generalis,

In a place ther goode ale ys

Anno regni regitalis

Edwardi nullateni

On yestern day in Feuerere - pe yere passyth fully;

As Nought hath wrytyn; here ys owr Tully,

Anno regni regis nulli.

The legal idioms, decoded, indicate that the record was taken on 'the yesterday, February, in an unknown year, in the regnal year of Edward of nothing', adding later 'in the regnal year of no king'. This curious vacuum of time led Smart to believe that the play must have been written or performed at some point during the Lancastrian Readeption. In October 1470, Edward IV fled the Lancastrian forces led by his cousin, Richard Neville, duke of Warwick, and his brother George, duke of Clarence, and left England for the Low Countries, ceding the kingdom to Henry VI. Edward was not able to reclaim the throne until April 1471, after landing in Yorkshire in March and riding south, reconciling with Clarence en route. Given that Edward did not hold the kingship for these seven months, if the play were performed during that time, the irreverent worldlings would refer to him as 'Edward of nothing'. Since the play would be performed at Shrovetide, the 'yesterday of February', then, could only refer to February $1471 .{ }^{22}$ With regards to authorship, Smart contended that the play was written by 'a Cambridgeshire man who was especially familiar with the neighbourhood around the town of Cambridge', since the locations associated with the men named in the play are near Cambridge and Bishop's Lynn, Norfolk. ${ }^{23}$ Smart further considered the order in which the 
worldlings describe their passage, with New-Guise travelling a relatively short distance around Cambridge, but the other two worldlings jumping back and forth between the two counties, and concluded that the imbalance stemmed from a familiarity with Cambridgeshire over Norfolk, therefore indicating a Cambridge rather than a Bishop's Lynn affiliation for the author. ${ }^{24}$ Centring even more closely on a date, Marshall noted that although a St Edmunds Guild would meet four times a year, only one, the feast of St Peter's Chair, on 22 February, took place during Shrovetide. In 1471, this feast fell just before Shrove Tuesday, which occurred on 26 February, and would have been marked by a Saturday feast on 23 February. ${ }^{25}$ Through the consultation of guild records, Marshall also identified either the Cambridge or Bishop's Lynn St Edmunds Guilds as a likely audience for the play, and offered Nicholas Meryll, mentioned above, as a potential author, one of the most detailed sets of conjectures regarding authorship of an anonymous medieval work. ${ }^{26}$

Marshall's conclusions do not take into account three arguments against Smart's February 1471 date. Eccles notes that the play 'could not, however, have been written at this time, since "Master Alyngton of Botysam", mentioned in line 514, was in exile with Edward from September 1470 to April 1471', citing Wedgwood's History of Parliament. ${ }^{27}$ Thomas Jambeck and Reuben Lee arrived at a wholly different conclusion based on a reference by Nought to a pardon 'grawntyde of Pope Pokett' (1. 144). Noting that 'while Nought's rejoinder may very well represent a conventional, albeit indelicate, jibe at papal avarice', possibly the worldling was actually referring to John Pokett, prior of Barnwell Abbey, who died in $1464 .{ }^{28}$ When considering the numismatic evidence discussed by Baker, Jambeck and Lee concluded that 1464 was the only possible year for the play's composition. This conclusion seems not to have acquired much currency, however, since the death of John Pokett need not mean the death of jokes at his expense, and since the preponderance of the remaining prosopographical information insists on a later date. Finally, a 1995 edition of the play by Knittel and Fatic supported a date outside of the Lancastrian Readeption, arguing that it is very doubtful that the name Edward would have been used while Henry was king and unlikely while there was any doubt as to who would win out in the struggle'. ${ }^{29}$ These two arguments against the February 1471 date, that Alington was out of the country, and that the use of Edward's name would have been politically foolish, are not unchallengeable. To the first argument, Eccles' reliance on Wedgwood's History is flawed inasmuch as J. S. Roskell's biography of William Alington considers Alington's accompanying Edward IV in exile to be 
only a possibility. ${ }^{30}$ To the second, the reception of any political commentary within the play would depend on both audience and patron. If the play was intended to be overtly political, as may be the case here as much as it was for Wisdom, then a reference to Edward IV as king could signal solidarity among a Yorkist audience and condemn those who supported the Lancastrian rebellion, or insist on loyal behaviour from those who might contemplate supporting Henry VI.

Given the somewhat irreverent description of Edward as 'Edward of nothing', one may be inclined to consider the play to be, if anything, Lancastrian in its leanings. The argument for Yorkist sympathies, in addition to the Yorkist ties of the three men avoided by the worldlings, may be supposed from the speaker. The worldlings with their jibes are not figures to be emulated, as is made clear earlier in the play when the worldlings attempt to lead the audience in the blasphemous 'Crystemes songe' (332-343). The humour of these characters is predicated on their outlandish and transgressive behaviour, and their possible mockery of Edward should be read in this context. Also, given that Wisdom is decidedly critical of the Lancastrian de la Poles, we might cautiously assume that Mankind would reflect similar sentiments.

Even if the conclusions of Smart and Marshall are accepted, there remain certain points which ought to be addressed. Marshall's study situates the play geographically and temporally, but it does not examine the lives of the men named. All studies following Smart have relied on his prosopographical research, meaning that no research has sought to re-examine or add to Smart's initial findings. The result of this situation is lacunae in the data: to provide just one example, while most scholars have concluded — based only on Smart - that three men are to be spared for reasons of judicial authority, no study has satisfactorily identified 'Hamonde of Soffeham' (515). Smart himself says of Hamond only that there is some difficulty in determining if 'Soffeham' is the Swaffham of Norfolk, or Swaffham Prior or Swaffham Bulbeck of Cambridgeshire, and that both locales had Hamonds living in them during the period. ${ }^{31}$ A re-examination of the men named produces, then, not only clarifications of Smart's work, but also provides possible reasons for their being named, which in turn may support the 1471 date suggested by Smart and Marshall.

The easiest person to identify on the list, William Alington, serves well as an example of the ties between local and national politics, and the ability of the gentry to ride out national changes while retaining pre-eminence within local power structures. Alington, the fourth in his family to bear the name 
William, came from a long line of gentry with close ties to the crown, with a grandfather, father, and brother receiving numerous political appointments on both the national and local levels. ${ }^{32}$ Alington's father, William [III], had a relatively distinguished career within the counties of Cambridgeshire and Huntingdonshire, acting as MP, JP, sheriff, and escheator, ${ }^{33}$ and William's older brother John, though similarly localized in his appointments, served as $\mathrm{JP}$, sheriff, and escheator, and was a retainer to the duke of York. ${ }^{34}$

The specific appointments that John and his father William [III] held in East Anglia are important to note, since loyalty to certain peers, particularly those who were closely tied to the crown, brought certain benefits throughout the fifteenth century. Roger Virgoe has noted that appointment to the offices of sheriff, escheator, and the commission of the peace in particular indicate that 'there was some demand from below to sit on the commission and pressure from magnates to nominate their clients to it'. ${ }^{35}$ While this appears to be the case for the Alingtons in general, the heights to which a member of the gentry could rise are even clearer in the case of William [IV], the person named in line 514. In his career, a long-standing family history of regular appointments to positions of local authority was strengthened by bonds to magnates through gentry marriage.

William Alington [IV], born sometime after 1428, first appears in the bishop's register at Ely, where his licence to marry Joan Ansty is recorded on 9 January 1457. ${ }^{36}$ Joan's father, John, was steward of Zouches Manor within Fulbourn, Cambridgeshire, and held land in Fulbourn under John Butler, earl of Ormond (who was attainted by Edward IV in 1461 for his support of Henry VI) and under Henry Bourchier, earl of Essex (to whom Edward granted Ormond's Fulbourn estates in 1462). ${ }^{37}$ Alington first appeared on royal commissions in 1457 , and was appointed with his father to act as JP for the town and county of Cambridge a total of eleven times from 1457 to 1460 , as well as escheator for Cambridgeshire and Huntingdonshire on 7 November 1458. ${ }^{38}$ That Alington received these appointments while the Lancastrians were in complete control does not pass unnoticed by Roskell, who notes 'that he was clearly not active as a Lancastrian partisan at this time' since 'it was the Yorkists who reappointed him to the commission of the peace for the county and even gave him a place on the quorum of the bench on 26 August 1460, that is, after the Yorkists' recent victory at Northampton had placed the administration of the county at their disposal'. ${ }^{39}$

After Edward IV came to power, William was consistently listed as Jp for both the town and county of Cambridge and Huntingdonshire between 1461 
and $1466 .{ }^{40}$ During this decade, William received several other appointments as well; on 1 December 1461, 3 February 1462, and in August 1463, William was appointed to commissions of oyer and terminer to investigate the complaint that the tenants of Barnwell Priory had thrown off their allegiance. This is the same Barnwell Priory administered by the John Pokett mentioned above. ${ }^{41}$ As Roskell notes, it is possible that William began his parliamentary career in 1461 to 1462 - at the same time that his brother as sheriff oversaw the local elections - but the Cambridge returns for this parliament and the next were lost. ${ }^{42}$ The returns for Edward IV's third parliament do remain, however, and we know that William's brother-in-law John Ansty was elected MP for Cambridgeshire, while William was elected for Plympton, Devon. ${ }^{43}$ Alington continued to receive various appointments in the last two years of the 1460s, including a March 1468 commission to inquire into the escape of felons from Cambridge gaols, and an additional appointment to a commission of the peace in 1468 for Cambridgeshire. ${ }^{44}$

Alington's name falls off the records from the Lancastrian Readeption of 1470 to 1471 . In an effort to explain this absence, Wedgwood claims that 'in September 1470 [William] went into exile with Edward IV'. ${ }^{45}$ On this matter, Roskell remarks only:

It is possible that Allington shared Edward IV's brief exile in Flanders during Henry VI's brief restoration in 1470-1 (and certainly he was dropped from his commissions of the peace in both Cambridgeshire and Huntingdonshire). If this was so, it would in itself account for the rapidly accelerated growth of Allington's influence in Court circles in the few years of his life that remained to him, after Edward IV had regained his throne. ${ }^{46}$

William's absence from commissions could, however, just as likely be explained by Henry VI's unwillingness to retain potential Yorkist partisans, for there seems to be no record of William's having joined Edward IV in exile in any of the chronicles detailing Edward's reign, nor any of the major biographies dealing with the king, nor in any published rolls, and Wedgwood himself provides no reference. Further, the fact that Nought refuses to burgle or otherwise trouble Alington's household would seem to indicate that Alington was, if not present at the production of the play itself, at least not in exile and therefore wholly unable to prosecute the worldling.

William's greatest successes followed Edward's return, and these events likely come after the composition and first production of Mankind, if we 
accept Marshall's hypothesis. A brief summary of William's movement to the national sphere nevertheless reveals something of Edward's approach to dealing with the localities. On 11 May 1471, following the battle of Tewksbury, Alington was appointed to commissions of array in Cambridgeshire and Huntingdonshire, and two months later was appointed to a royal commission to punish or capture rebels in Essex. ${ }^{47}$ One year later, William was elected by the parliament of $1472-5$ to act as their Speaker. ${ }^{48}$ In the same parliamentary year, on 20 February 1473, William was brought even closer into the court circle when a group of twenty-five personages of the realm, including the queen, the king's brothers, the queen's brother, the chancellor of England, three bishops, the earl of Shrewsbury, the king's chamberlain, two royal judges, the prince of Wales's chancellor and chamberlain, and William, were appointed to be tutors and councillors to the prince of Wales. ${ }^{49}$

At the end of June 1475, Alington, with many others, was appointed to act on the Great Council of Regency which oversaw the prince of Wales's role as warden of England; it is probable that from this point William was also an active member of the king's privy council. ${ }^{50}$ In 1477, Alington was again called to parliament for Cambridge, and on 20 January 1478, he was again elected as Speaker. ${ }^{51}$ William's last great activities of moment came upon him late in his life. During the 1478 parliament, Alington spoke for the Commons on the matter of the king's brother, the duke of Clarence, who was condemned for high treason on 7 February 1478 and, after Alington appeared before the Lords and issued the Commons' demand for death, executed in the Tower. Shortly thereafter, William received $£ 100$ for 'good and laudable service as his reward for his Speakership'. 52 The inquiries into the late Clarence's estates afforded Alington further opportunities to assist the King, and he was appointed on both 16 March and 4 May to inquire into the Clarence estates in Cambridgeshire. ${ }^{53}$ Also in 1478, Alington was appointed one of the king's councillors for life, and received portions of Clarence's lands; by this time he was also raised to the position of the prince of Wales's chancellor for the duchy of Cornwall. ${ }^{54}$ Unfortunately for Alington, these shining new signs of royal favour came to him only shortly before his death, for he died on 16 May 1479 without issue. 55

This biography indicates that although Alington's power was limited to East Anglia before the Readeption, he was also tied to Yorkist peers though his brother and his wife, and that possibly because of these personal ties he received the appointments he did. As a result of both his official authority and his unofficial ties to York, Alington was likely a figure to be dealt with 
carefully, if at all, in East Anglia, even while Henry VI was attempting to reassert Lancastrian control over the localities. We should then be unsurprised that he is avoided by Nought in the play, and look to see whether this nexus of the personal and the political also appears in both of the other men avoided by the worldlings.

The identity of 'Hamonde of Swoffham' proved difficult for Smart to confirm with any certainty; he noted that the location could be applied either to Swaffham in Norfolk, fourteen miles from Bishop's Lynn, or to Swaffham in Cambridge, commonly referred to as Swaffham Bulbeck. ${ }^{56}$ Despite the proximity of Swaffham Bulbeck to Bottisham and Cambridge (see maps), Smart asserted that the Norfolk Swaffham is a better choice:

[A]s the writer seems to be making 'a deliberate attempt to keep up interest in two different districts by local allusions equally distributed,' and as the substitution of a Cambridgeshire town would destroy the balance between the Cambridgeshire and Norfolk places, making the proportion 6 to 3, instead of 5 to 4 , it is perhaps better to retain the Norfolk Swaffham. ${ }^{57}$

This conclusion neglects another possible reading, however: although there are only nine locations listed, there are ten men. 'William Fyde' (503) is not given a location. For the sake of achieving a balance between Cambridgeshire and Norfolk, Fyde would have to come from Norfolk. However, the only Fyde for whom Smart could find reference was a John Fydde of Waterbeach, which is located just outside of Cambridge to the northeast, and no evidence appears for any Fydes living in Norfolk. ${ }^{58}$ If we accept that there is no need to create a balance between Cambridgeshire and Norfolk, we can then consider Swaffham Bulbeck, Cambridgeshire, to be a possible location for Hamond.

Eccles writes in his notes on lines 505 to 515 that Hamond is 'probably, as Professor Bruce Dickens suggests, the William Hamond whose brass dated 6 Feb. 1482 was once at Swaffham Bulbeck, Cambs. ${ }^{59}$ Eccles is likely correct in this supposition, but gives no explanation as to why Hamond would be avoided by the worldlings. Unlike Alington, William Hamond was never appointed to a commission of the peace nor as sheriff, and appears only sporadically in the documents of the period. As is the case with Alington, Hamond can nevertheless be tied to Yorkist magnates of the period. Hamond was the owner of a large manor within Swaffham later called Momplers. ${ }^{60}$ William's father, Nicholas, who purchased the Momplers estate to be incorporated into his own holdings of roughly one hundred-forty acres, was also the receiver 
of the Ingoldisthorpe estate from about 1435. ${ }^{61}$ The Ingoldisthorpes had been tied through various activities to the Alingtons for several generations, and were, like the Alingtons, tied to both Lancastrian and Yorkist peers. ${ }^{62}$ In 1432, John, the first Baron Tiptoft, secured the wardship of Sir Edmund Ingoldisthorpe, who was also grandson to Walter de le Pole, and married him to his daughter, Joan. ${ }^{63}$ While the first Baron Tiptoft was a councillor to Henry VI in the 1420s and 1430s, his son, the earl of Worcester, was bound politically and by marriage to Edward IV: he married Cecily Neville, cousin to Edward IV, in $1449 .{ }^{64}$ These close familial relationships - John Tiptoft's marriage to Cecily Neville, and his sister's marriage to Edmund - seem to have benefited the Hamonds as well, since William Hamond was appointed as escheator for Cambridgeshire and Huntingdonshire on 5 November 1468 until the same date the following year. Likely due to this position of authority, he was avoided by the worldlings, although like Alington, Hamond's name drops off the rolls during the Readeption. ${ }^{65}$

As escheator for the county, Hamond would have had some authority, and would have been in regular association with other figures of justice. Additionally, Hamond's position allows us to make a reasonable inference about Nought's line following the mention of his name: 'I xall spare Master Alyngton of Botysam, / Ande Hamonde of Soffeham, /For drede of in manus tuas qweke!' (1l. 514-6). The 'in manus tuas [into thy hands]' has obvious biblical allusions, both as Christ's last words on the cross in Luke 23:46, and as a line from Psalm 30, which was used in the sacrament of extreme unction. Due to these contexts, as Smart says, 'and also because many condemned prisoners wanted to die with Christ's last words on their lips, the phrase "in manus tuas" was constantly heard at executions, and became a slang term for execution itself'. ${ }^{66}$ Indeed, the anatine utterance 'qweke!' is almost certainly a sign of stage-play, with Nought miming his own hanging for attacking the wrong man. Most crucial to this joke, however, is the role of the escheator in the execution of felons; once anyone was convicted of a capital offence, his or her property would be ineligible for inheritance, and the escheator would take any such property into the King's hands. Thus the phrase 'in manus tuas' alerts us to Hamond's authority in several ways. Nought pretends to fear execution if he goes after a man of such authority, an execution in which Hamond would be responsible for taking Nought's property. This reading allows for two equally valid and intended meanings of Nought's 'in manus tuas': both that such a phrase would be customary for a felon to say before execution, and, more literally, 
Nought would effectively be commending his possessions into Hamond's hands on behalf of the king.

This identification, more than anything else, argues against a performance date of February 1471. William Hamond was escheator only from 1468 to 1469; he did not, in fact, have any position of authority following that date. Given the mock court record, however, as well as Hamond's continued ties to the Ingoldisthorpes and the Tiptofts, it remains likely that William Hamond may well have been regarded as a man of some influence in the county a little over one year following his appointment. With Hamond's position established, however, we can now turn to the third man to remain unmolested by the worldlings, whom Nowadays declares to be a 'noli me tangere' (512).

Both Smart and Eccles proposed that the line, 'I xall spare Master Woode of Fullburn' (511), referred to Alexander Wood of Fulbourn, Cambridgeshire who died on 5 December $1479 .{ }^{67}$ Similar to both Alington and Hamond, Wood was a person of some importance in the Cambridge area. Even more so than Alington, Wood exemplifies the great ability of the gentry to rise in status during the fifteenth century. Though he came from a yeoman family, Wood had as a patron the Cardinal Archbishop Thomas Bourchier and was, by the time of his death, in possession of a five-hundred-acre estate in Fulbourn. ${ }^{68}$ Again, as with both Alington and Hamond, Wood benefited from his ties to York and Edward IV, here through Cardinal Bourchier. Bourchier crowned both Edward and his queen, Elizabeth Woodville, and Edward himself petitioned Pope Paul II to make Bourchier a cardinal. As early as 5 October 1454, the archbishop appointed Alexander Wood as his receivergeneral in Sussex, Surrey, Middlesex, and Hertfordshire, adding that he was 'de fidelitate et circumspeccionis industria dilecti nobis in Christo Alexandri Wode plenius confidentes [fully confident in the faithfulness and circumspection of Alexander Wood, esteemed by us in Christ]'. ${ }^{69}$ Through this commission, Wood was in contact with some of the most powerful men of the realm, including the archbishop's brother, John, and his nephew, Humphrey, as occurred on 19 June 1457, when the three, among others, were commissioned to administer the goods of a deceased widow in the jurisdiction of the archbishop. ${ }^{70}$ Wood was not the only man listed in Mankind to be tied to Bourchier; a similar commission on 21 November 1461 called on William Alington, along with John, Fifth Baron Scrope of Bolton, who had fought for Edward IV and had been seriously injured at the Battle of Towton only eight months earlier. ${ }^{71}$ Throughout the 1470 s, Wood was a member of various commissions, and served a number of times with Alington, 
including the 16 March 1478 commission of enquiry into the value of the late duke of Clarence's Cambridge lands. ${ }^{72}$

Smart notes Nowadays' comment that Wood is a 'noli me tangere [a touch-me-not]', 'that is to say, he is a man to be let alone', but, unaware of Wood's own very close connections with royal and ecclesiastical authority, relies purely on Wood's ties to Alington to explain the worldling's reticence. ${ }^{73}$ While it is true that Wood was not a JP in February 1471, the stink of authority is not easily washed off, and Wood was surely a 'noli me tangere' for his own past role as a justice and his ties to the Bourchiers.

Since the above conclusions have relied on the formula that authority equals protection, we must now move into murkier territory to investigate those whom the worldlings do not fear to bother. Since they would, by this hypothesis, not be persons of authority, and without ties to York, it would stand to reason that they may also be persons with less documentary evidence. This seems to be the case, for of the seven remaining men (including William Fyde), the only person to achieve any positions for which evidence remains is 'Master Huntyngton of Sauston' (505). This name likely refers to Thomas Huntingdon, who sat as sheriff for Cambridgeshire and Huntingdonshire from 5 November 1479 to 5 November 1480 , and died in $1498 .{ }^{74}$ While the evidence for Thomas Huntingdon is rather limited, it does allows us to presume that, though a member of the gentry, he may have been somewhat less well connected than Alington, Hamond, or Wood. That the wordlings do not fear to rob him can only be attributed to the fact that Thomas was, at the time of the play's composition, still roughly ten years from acting as an administrator of justice for the county in any capacity.

There seems to be even less extant evidence for the other six persons named: 'Wyllyam Patryke of Massyngham', 'Pycharde of Trumpyngton', 'Williham Bakere of Walton', 'William Thurlay of Hauston', 'William Fyde', and 'Richard Bollman of Gayton'. A will proved in 1499 at Norwich for a William Patrick of Massingham Magna possibly refers to the Patrick of the play, making him the first Norfolk resident encountered thus far. ${ }^{75}$ 'Pycharde of Trumpyngton' (507) is likely a member of a Cambridgeshire gentry family that rose to local pre-eminence after the composition of the play. ${ }^{76}$ William Baker is likely the same man who died on 12 March 1491; left land in East Walton, Norfolk to his son William; and is recorded in several property transactions in the Walton area from the end of the fifteenth century. ${ }^{77}$ William Thurlay is a probable relative of the 'Johannes Thyrlowe de Hawkeston' of Hauxton, Cambridgeshire mentioned in the 1450-1 accounts of the Priory 
of St Radegund. ${ }^{78}$ As mentioned above, William Fyde is likely to be a relative of the John Fydde of Waterbeach, Cambridgeshire, also listed in the 1450-1 Priory accounts. ${ }^{79}$ For Richard Bollman, there appears to be no information to be found for even a family by that name. There is little doubt, however, that that Gayton referred to as Bollman's town of residence is the Gayton in Norfolk. ${ }^{80}$

These additions to the prosopographical evidence that we have for the persons named in Mankind contribute to our reading in three ways. First, Smart's contention that the author of the play was a local Cambridge man who laid out the worldlings' travels in such a way as would be reasonable for travel by foot through the area appears likely, but should be qualified. ${ }^{81}$ Smart argues that the playwright was unfamiliar with towns in Norfolk, but this may not be the case. Titivillus names one man, Fyde, who, if he lived in Waterbeach, would have been north-northeast of the town. New-Guise, who speaks next, claims men in the towns of Sawston, Hauxton, and Trumpington, which lay in a straight line three to four miles south of the town. (see figure 1). Nowadays goes further afield, beginning in Norfolk with Walton and Gayton (see figure 2), but refusing to return nearly forty miles to take Wood in Fulbourn. Nought's group is similarly reasonable, as the worldling also skips Cambridgeshire, avoiding the two adjacent villages of Bottisham and Swaffham, and staying in Norfolk at Massingham, tens of miles to the east. (see figures 2 and 3). In this light, the author's knowledge of East Anglian geography appears quite sound, and his Cambridge affiliation must be argued from the fact that he chooses to use seven Cambridge towns to only three in Norfolk, and the fact that all three persons of authority are from Cambridge. This first point leads to the second, that the preference for Cambridgeshire points persuasively to authorship by a man such as Nicholas Meryll, from Cambridge but relocated to Bishop's Lynn, as John Marshall has argued.

The third and final hypothesis we can draw from the evidence is rather more tentative: that we may be able to read Mankind not only as a simple morality play, but also as a play that was overtly political to its original audience. Although, in a recent study of Mischief's mock court roll, Jessica Brantley and Thomas Fulton suggest that the play 'recommends a healthy suspicion of kings' ${ }^{82}$ subversively suggesting that 'royal authority devolved into an unconvincing show, becoming explicitly "like a play", 83 this argument centres on the fact that political instability gave rise to shifting and ambiguous loyalties. This present study of the men named in Mankind shows, however, that it is precisely in such an unstable atmosphere that the gentry gain opportunities 


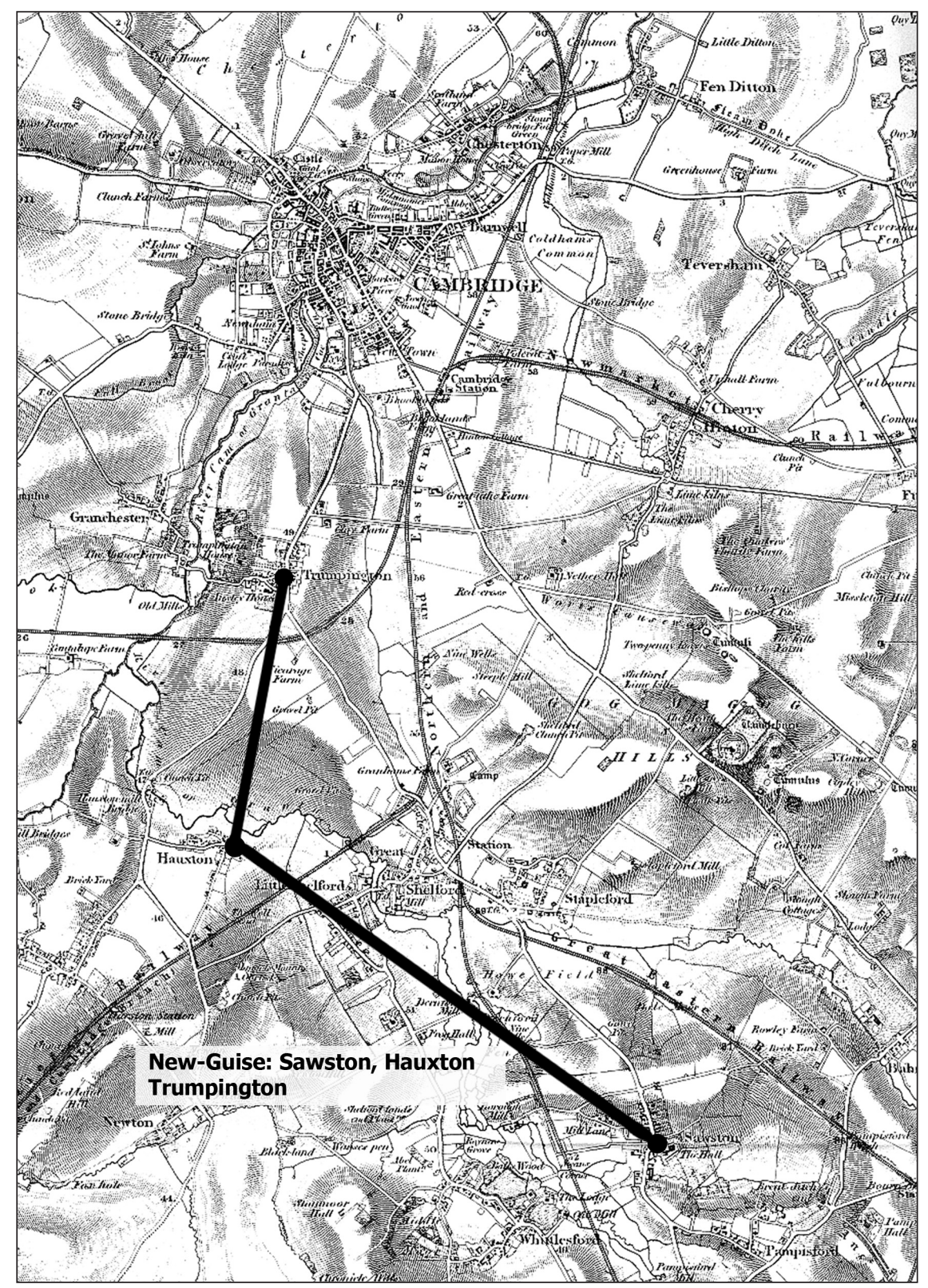

Fig. 1. New-Guise's route south of Cambridge. Ordnance Survey. 'Sheet 51' [map]. First Series. London: Ordnance Survey, 1836. 


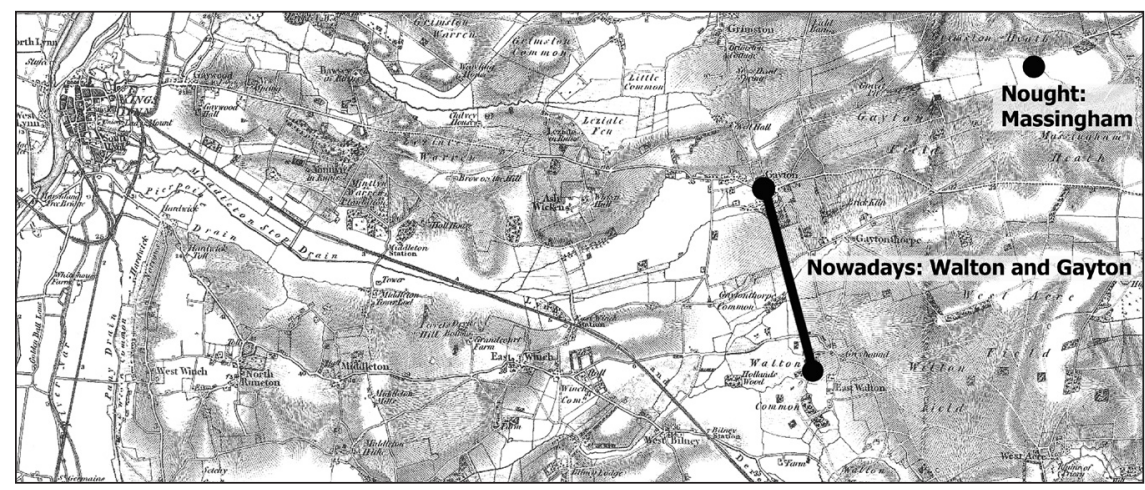

Fig. 2. Nowadays' route east of King's Lynn. Ordnance Survey. 'Sheet 51' [map]. First Series. London: Ordnance Survey, 1836.

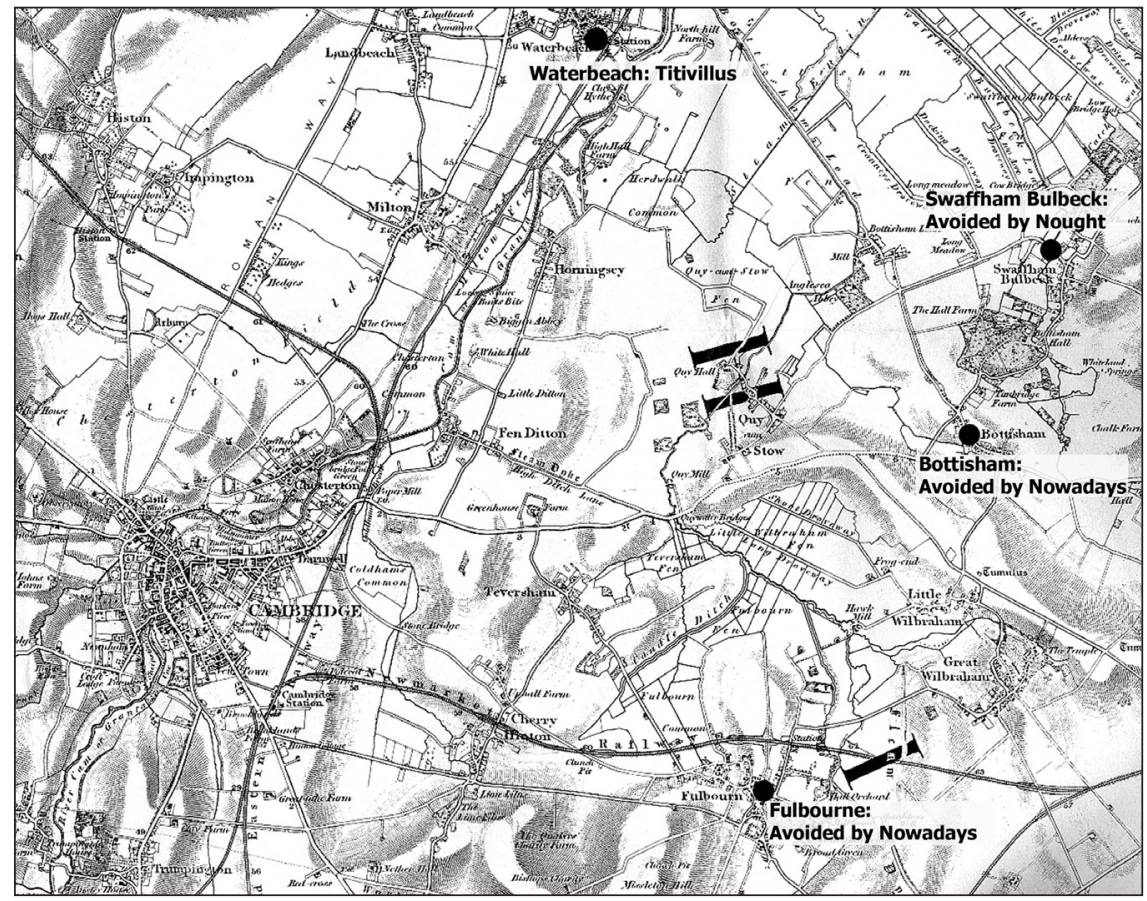

Fig. 3. Locations east of Cambridge'. Ordnance Survey. 'Sheets 65 and 69' [map]. First Series. London: Ordnance Survey, 1824. 
to rise in power by offering their loyalty. The factional battles of the fifteenth century led to an effort by the crown to incorporate pre-existing local power structures - once dominated by personal loyalties and the rewards of household positions - into a more official state. While the local power structures that bound together the peers and the gentry were often able to withstand the violent shifts in power from above due to a bottom-up desire to retain local authority, they were also nevertheless influenced by top-down attempts by the magnates to solidify county loyalties by granting these positions of local authority. When, therefore, all three persons avoided by the worldlings are not only former officers of royal authority in East Anglia, but also men tied to Yorkist magnates situated in East Anglia, the themes of the play can be read to apply to this political context. Salvation - in this case from robbery or other molestation by the worldlings - might equate with constancy, in this case loyalty to a deposed king, 'Edward of nothing'. If this sort of constancy is taken into account when considering the larger moral message of the play - critical of changing fashions, vanity, and the refusal of right order - a new strength can be added to Larry Clopper's reading of the play that 'to fall $\ldots$ is to go to court, to become a fop'. ${ }^{84}$ There may have been many in Cambridgeshire or Norfolk who hoped that they might benefit from a new king in power, a new king whose prior reign was marked by the abuses discussed in Wisdom, and that they might be elevated in local politics through a new cadre of favoured nobility. If loyalty to a new court is considered to be devilish new guise, now-a-days, and nought, then one can appreciate the political acumen and prescience of a Cambridgeshire monk in such an unsettled time.

\section{Notes}

1 This title quotation (1. 691) and all others from Mankind are from Mark Eccles's edition in The Macro Plays (London, 1969), cited parenthetically in the essay.

2 The article appeared in two parts: 'Some Notes on Mankind [Continued]' and 'Some Notes on Mankind [Concluded]', Modern Philology 14.1 and 14.5 (1916), 45-58 and 293-313.

3 Marshall's article appeared in European Medieval Drama 1 (1997), 105-19.

4 John L. Watts, Henry VI and the Politics of Kingship (Cambridge, 1996), 91.

5 Bertram Wolffe, Henry VI (London, 1981), 109.

6 Ibid, 112.

7 Ibid, 227. 
8 Ralph Griffiths, The Reign of King Henry VI: the Exercise of Royal Authority, 14221461 (London, 1981), 284.

9 For a fuller discussion of the career of Tuddenham, see Wolffe, 122-3, and his entry in the Oxford Dictionary of National Biography.

10 Ibid, 123.

11 Griffiths, 585-586.

12 Ibid, 789.

13 Ibid, 864.

14 Ibid.

15 Ibid, 865.

16 John Marshall, "Fortune in the Worldys Worschyppe”: The Satirising of the Suffolks in Wisdom', Medieval English Theatre 14 (1992), 45-6.

17 Ibid, 60.

18 Smart, 'Mankind [Continued]', 45.

19 Donald C. Baker, 'The Date of Mankind', Philological Quarterly (1963), 90.

20 Smart, 'Mankind [Continued]', 45.

21 Ibid, 45; Richard Beadle, 'Monk Thomas Hyngham's Hand in the Macro Manuscript', New Science out of Old Books: Studies in Manuscripts and Early Printed Books in Honour of A. I. Doyle (Aldershot, 1995), 314-41.

22 Smart, 'Mankind [Continued]', 45.

23 Ibid, 116.

24 Ibid, 116-17.

25 Marshall, 113.

26 Ibid, 112.

27 Eccles, xxxviii.

28 Jambeck and Lee, 'Pope Pokett', 511.

29 Frank Knittel and Grosvenor Fattic. A Critical Edition of the Medieval Play Mankind. (Lewiston, 1995), 18. See also Baker, 91.

30 J.S. Roskell, 'William Allington of Bottisham, Speaker in the Parliaments of 1472-5 and 1478 (Paper II)', Proceedings of the Cambridgeshire Antiquarian Society 52 (1958), 47.

31 Smart, 'Mankind [Continued]', 55.

32 The grandfather to the William [IV] named in the play, also named William [II], was tied to Richard II. For fuller particulars, see J.S. Roskell, 'William Allington of Horseheath, Speaker in the Parliament of 1429-30 (Paper I)', Proceedings of the Cambridgeshire Antiquarian Society 52 (1959), 32. For additional details on the early Alingtons, see Edward Hailstone, Jr, The History and Antiquities of the Parish of 
Bottisham and the Priory of Anglesey in Cambridgeshire (Cambridge Antiquarian Society Publications, Octavo Series, VII. Cambridge, 1873), 107.

33 William [III] (1400-5 July 1459) was MP for Cambridgeshire for the parliaments of 1433, 1437, and 1439-40, and JP from 1439 to his death. See Josiah C. Wedgwood and Anne D. Holt, The History of Parliament: Biographies of the Members of the Commons House 1439-1509 (London, 1936), 8. William was also escheator for Cambridgeshire and Huntingdonshire from 23 November 1436 to 23 November 1437, and sheriff for the same two counties from 7 November 1437 to 3 November 1438 and 8 February 1451 to 8 November 1451; see A.C. Wood (ed.), List of Sheriffs; List of Escheators for England and Wales, (London, 1971), 14.

34 Hailstone, in The Parish of Bottisham (111), identifies William as being the elder son. Roskell, however, in 'Allington (Paper II)', 43, claims John to be the elder, presumably because John retained his father's estate at Horseheath. John was escheator for the counties of Cambridgeshire and Huntingdonshire in 1447-8, and Edward IV's first sheriff for the same counties from 6 March 1461 to 7 November 1462; see Roskell, 'Allington (Paper II)', 43; and List of Sheriffs, List of Escheators, 14).

35 Roger Virgoe, 'The Crown, Magnates, and Local Government in Fifteenth-Century East Anglia', J.R.L. Highfield and Robin Jeffs (eds), The Crown and Local Communities in England and France in the Fifteenth Century, (Gloucester, 1981), 79.

36 Roskell, 'Allington (Paper II)', 44.

37 'Fulbourn: Manors and other estates', A History of the County of Cambridge and the Isle of Ely: Volume 10: Cheveley, Flendish, Staine and Staploe Hundreds (north-eastern Cambridgeshire) (2002), 136-143. [VCH: Cambs]

38 Calendar of Patent Rolls, Henry VI, 1452-61 (London, 1901-11), 622; List of Escheators, 14.

39 Roskell, 'Allington (Paper II)', 44.

40 CPR, 1461-7, 560-1, 565.

41 Smart, 'Mankind [Continued]', 48; Roskell, 'Allington (Paper II)', 45. CPR, 1461-7, 281.

42 Roskell, 'Allington (Paper II)', 46. Wedgwood includes both parliaments in Alington's biography, 9.

43 Roskell, 'Allington (Paper II)', 46; and Wedgwood, 9.

44 Roskell, 'Allington (Paper II)', 46; and Wedgwood, 9; CPR, 1467-77, 609.

45 Wedgwood, 9.

46 Roskell, 'Allington (Paper II)', 47.

47 CPR, 1467-77, 285, 287.

48 Prome: The Parliament Rolls of Medieval England, 1275-1504 (Leicester, 2005), Edward IV, 1472 October, vi-4, col. a, 6. 
49 Roskell, 'Allington (Paper II)', 49.

50 Ibid, 52, 54.

51 Prome, vi-169, col. a, 9.

52 Roskell, 'Allington (Paper II)', 53.

53 CPR 1476-85, 109, 111.

54 Ibid, 142; Roskell, 'Allington (Paper II)', 54.

55 Calendarium Inquisitionum post Mortem sive Escaetarum, vol. 4, (London, 18061808), 392.

56 Smart, 'Mankind [Continued]', 54.

57 Ibid, 114.

58 Ibid, 55.

59 Eccles, 222.

60 VCH: Cambs, vol. 10, 257.

61 Ibid, 257.

62 In his 8 June 1420 will, Sir John Ingoldisthorpe named William Alington [II] one of his executors. See W.M. Palmer, A History of the Parish of Borough Green Cambridgeshire (Cambridge, 1939), 89. In 1456, William Alington [presumably III] was named in an order to the escheator of Norfolk to deliver to Alington and others any issues taken from the manor of 'Ingaldesthorpys maner' (Calendar of Close Rolls 1454-61, 156).

63 Roskell, The History of Parliament: The House of Commons, 1386-1421, 625.

64 CPR 1446-52, 242.

65 List of Escheators, 14; Calendar of Fine Rolls 1461-71, 222.

66 Smart, 'Mankind [Concluded]', 107.

67 Ibid, 49; CFR 1471-85, 517.

68 VCH: Cambs, vol. 10, 137, 146, 155; Smart, 'Mankind [Continued]', 49.

69 Registrum Thome Bourgchier, Cantuariensis archiepiscopi, A.D. 1454-1486, F.R.H. Du Boulay (trans. and ed.) (Oxford, 1957), 14-16.

70 Ibid, 181.

71 Ibid, 200.

72 CPR 1476-85, 109; CPR 1467-77, 406, 609; Smart, 'Mankind [Continued]', 50.

73 Smart, 'Mankind [Continued]', 50.

74 Ibid; VCH: Cambs, vol. 5, 20-1; vol. 6, 252; vol. 8, 253-4; List of Sheriffs, 14; CFR 1471-85, 522.

75 M.A. Farrow, Index of Wills Proved in the Consistory Court of Norwich, 1370-1550, part II (Norfolk, 1943-5).

76 Smart finds mention in accounts of the Priory of St Radegund of a 'Johannes Pichard de Trumpyngton' in the accounts for 1449-50, a 'Pycchard de Trumpington' 


\section{John A. Geck}

in 1450-51, and, thirty years later, 'Willelmus Pychard',. (Smart, 'Mankind [Continued]', 51; Arthur Gray, The Priory of Saint Radegund, (Cambridge, 1898), 146). Thomas Pychard, presumably son or grandson of William Pychard, acquired Trumpington Manor in 1545 (VCH: Cambs, vol. 8, 253-4).

77 Smart, 'Mankind, [Continued]', 53.

78 Gray, Saint Radegund, 163.

79 Ibid, 173.

80 Eccles, 222.

81 Smart, 'Mankind [Concluded]', 116.

82 Brantley, Jessica, and Thomas Fulton, 'Mankind in a Year Without Kings', Journal of Medieval and Early Modern Studies 36.2 (2006), 344.

83 Ibid, 324.

84 Lawrence Clopper, 'Mankind and its Audience', Comparative Drama (1974), 353. 